Research article

Open Access

\title{
Synthesis and Antimicrobial Activity of Long-Chain 3,4-Epoxy-2-alkanones
}

\author{
William F. Wood \\ Department of Chemistry, Humboldt State University, 1 Harpst St., Arcata, California, 95521, U.S.A. \\ E-mail: wfw2@humboldt.edu \\ Sci Pharm. 2010; 78: 745-751 \\ doi:10.3797/scipharm.1009-02 \\ Published: $\quad$ October $9^{\text {th }} 2010$ \\ Accepted: $\quad$ October $8^{\text {th }} 2010$ \\ Received: $\quad$ September $1^{\text {st }} 2010$ \\ This article is available from: http://dx.doi.org/10.3797/scipharm.1009-02 \\ (C) Wood; licensee Österreichische Apotheker-Verlagsgesellschaft m. b. H., Vienna, Austria. \\ This is an Open Access article distributed under the terms of the Creative Commons Attribution License \\ (http://creativecommons.org/licenses/by/3.0/), which permits unrestricted use, distribution, and reproduction \\ in any medium, provided the original work is properly cited.
}

\begin{abstract}
3,4-Epoxy-2-dodecanone, a major component in the preorbital gland of the African grey duiker (Sylvicapra grimmia), showed antimicrobial activity in preliminary tests. The $\mathrm{C}_{11}$ to $\mathrm{C}_{17}$ homologues of this compound were prepared and their activity against several pathogenic dermal bacteria and fungi was tested. 3,4-Epoxy-2-dodecanone and 3,4-epoxy-2-tridecanone inhibited the growth of Trichophyton mentagrophytes at $25 \mu \mathrm{g} / \mathrm{mL}$. Moderate inhibition of the growth of the bacteria Propionibacterium acnes and the lipophilic yeast, Pityrosporum ovale, was seen for several of the homologues.
\end{abstract}

\section{Keywords}

Antifungal activity • 3,4-Epoxy-2-alkanones • Propionibacterium • Trichophyton

\section{Introduction}

Compounds with antimicrobial activity have been documented from the skin and skin glands of a number of mammalian species. (E)-3-Tridecen-2-one $(1 \mathrm{c}, \mathrm{n}=7)$ the major compound from interdigital glands of the black-tailed deer (Odocoileus hemionus columbianus) has significant antimicrobial activity [1-3]. Nonanal, octanal and heptanal were found in the hair of Mexican free-tailed bats (Tadarida brasiliensis mexicana) at concentrations known to inhibit the growth of pathogenic skin fungi [4]. Hair from the reticulated giraffe (Giraffa camelopardalis reticulata) also has nonanal, octanal and heptanal at high concentrations and $p$-cresol, indole, tetradecanoic acid and hexadecanoic acid, compounds that inhibit the growth of pathogenic skin fungi and bacteria [5]. Several antimicrobial long-chain alcohols were found in the interdigital glands of the American pronghorn (Antilocapra americana) [6]. In search of new antimicrobials from animal skin 
glands, 3,4-epoxy-2-dodecanone $(\mathbf{2 b}, \mathrm{n}=6)$, a major component in the African grey duiker's (Sylvicapra grimmia) preorbital skin gland [7] was prepared and assayed. It showed antifungal activity in preliminary tests, so the $\mathrm{C}_{11}$ to $\mathrm{C}_{17}, 3$,4-epoxy-2-alkanones $(\mathbf{2 a}-\mathbf{2 g}$, Scheme 1) were prepared and tested for antimicrobial activity. The activity of these compounds was compared to antimicrobial activity of the $(E)$-3-alken-2-ones $(1 \mathrm{a}-1 \mathrm{~g})$ from which they were prepared [3].

\section{Results and Discussion}

\section{Chemistry}

Naturally occurring, long-chain 3,4-epoxy-2-alkanones have infrequently been reported in the chemical literature. $\alpha, \beta-E$-Exoxyketones are easily prepared by reaction of hydrogen peroxide and sodium hydroxide with $\alpha, \beta$-unsaturated ketones $[7,8]$. This method was used with previously prepared long-chain (E)-3-alken-2-ones [3] to make the 3,4-epoxy2-alkanones in this report.

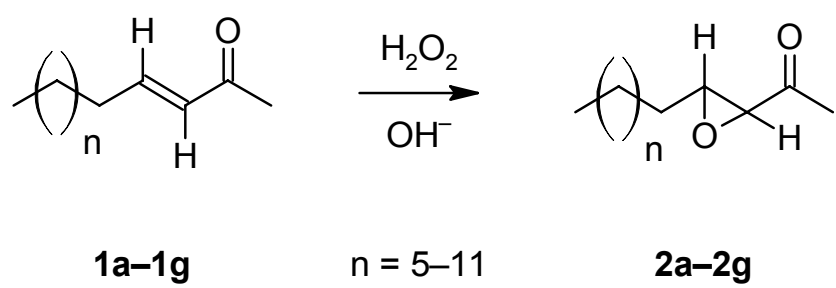

Sch. 1. Preparation of 3,4-epoxy-2-alkanones

\section{Antimicrobial Activity}

The minimum inhibitory concentrations (MIC) for Trichophyton mentagrophytes, Propionibacterium acnes and Pityrosporum ovale with the 3,4-epoxy-2-alkanones are listed in Table 1. 3,4-Epoxy-2-dodecanone (2b), the compound from the grey duiker, and 3,4-epoxy-2-tridecanone (2c) inhibited the growth of $T$. mentagrophytes at the same concentration, $25 \mu \mathrm{g} / \mathrm{mL}$. Activity against this fungus decreased at longer or shorter chain lengths. For the bacterium, $P$. acnes, the $\mathrm{C}_{11}$ to $\mathrm{C}_{15}$ homologues $(2 \mathrm{a}-\mathbf{2 e})$ were active at $100 \mu \mathrm{g} / \mathrm{mL}$, but the $\mathrm{C}_{16}$ and $\mathrm{C}_{17}$ homologues (2f and $\mathbf{2 g}$ ) were inactive. With the lipophilic yeast, $P$. ovale, the shorter chain-length compounds $\left[\mathrm{C}_{11}\right.$ to $\left.\mathrm{C}_{16}(\mathbf{2 a - 2 f})\right]$ were not active at $800 \mu \mathrm{g} / \mathrm{mL}$, but the $C_{17}$ compound $(\mathbf{2 g})$ was active at $200 \mu \mathrm{g} / \mathrm{mL}$. No activity was observed with the bacterium Staphylococcus aureus and the yeast Candida albicans. For all microorganisms tested, a control using the dissolution medium, dimethylformamide (DMF), had no activity.

Table 2 has the comparable inhibitory activity of the $(E)$-3-alken-2-ones (1a-1g) [3], the compounds that were used to prepare the 3,4-epoxy-2-alkanones in this report. The inhibition of $T$. mentagrophytes for both sets of compounds is similar, with activity for the $\mathrm{C}_{11}$ to $\mathrm{C}_{14}$ homologues, which decreases starting with the $\mathrm{C}_{15}$ compound. This suggests that these compounds have a similar mode of action with $T$. mentagrophytes. The inhibition of growth for $P$. acnes is quite different for these two series of compounds. The $(E)$-3-alken-2-ones $(\mathbf{1 a - 1 g})$ have activity increase with increasing carbon chain length. The shorter chain-length 3,4-epoxy-2-alkanones are not as active as the corresponding 
(E)-3-alken-2-ones and the longer homologues do not inhibit $P$. acnes. This suggests that these compounds have a different mode of action. The 3,4-epoxy-2-alkanones were almost inactive with the yeast $P$. ovale. Only the $\mathrm{C}_{17}$ compound showed slight activity. The activity of the $(E)$-3-alken-2-ones against $P$. ovale is moderate for the $C_{11}$ to $C_{14}$ homologues and ceases at longer chain lengths $\left(C_{16}\right.$ to $\left.C_{17}\right)$. This also suggests that these compounds have different modes of action. Both types of compound were not active against $S$. aureus.

Tab. 1. Minimum inhibitory concentration (MIC) of 3,4-epoxy-2-alkenones $(\mu \mathrm{g} / \mathrm{mL})$

\begin{tabular}{lccc}
\hline Compound & T. mentagrophytes & P. acnes & P. ovale \\
\hline 3,4-Epoxy-2-undecanone (2a) & 50 & 100 & $>800$ \\
3,4-Epoxy-2-dodecanone (2b) & 25 & 100 & $>800$ \\
3,4-Epoxy-2-tridecanone (2c) & 25 & 100 & $>800$ \\
3,4-Epoxy-2-tetradecanone (2d) & 50 & 100 & $>800$ \\
3,4-Epoxy-2-pentadecanone (2e) & 400 & 100 & $>800$ \\
3,4-Epoxy-2-hexadecanone (2f) & $>800$ & $>800$ & $>800$ \\
3,4-Epoxy-2-heptadecanone (2g) & $>800$ & $>800$ & 200
\end{tabular}

Tab. 2. Minimum Inhibitory Concentration (MIC) of 2-Alken-3-ones ( $\mu \mathrm{g} / \mathrm{mL})$

\begin{tabular}{lccc}
\hline Compound & T. mentagrophytes & P. acnes & P. ovale \\
\hline 2-Undecen-3-one (1a) & 100 & 50 & 100 \\
2-Dodecen-3-one (1b) & 100 & 25 & 100 \\
2-Tridecen-3-one (1c) & 25 & 12.5 & 100 \\
2-Tetradecen-3-one (1d) & 12.5 & 12.5 & 100 \\
2-Pentadecen-3-one (1e) & 800 & 6.25 & 400 \\
2-Hexadecen-3-one (1f) & $>800$ & 3.13 & $>800$ \\
2-Heptadecen-3-one (1g) & $>800$ & 3.13 & $>800$
\end{tabular}

The epoxide and double bond at the 3,4-position of the 3,4-epoxy-2-tridecanone (2c) and (E)-3-tridecen-2-one (1c) are important to the activity of these two compounds, since 2-tridecanone was inactive on bioassay with these microorganisms [2]. Thus, a possible mode of action for these two compounds may be an irreversible inhibition of an enzyme due to a nucleophilic attack at the 4-position. With $(E)$-3-tridecen-2-one this would be a 1,4-addition (Michael addition) and with 3,4-epoxy-2-tridecanone an epoxide opening. Other homologous 2-alkanones have not been tested, so a comparison with other compounds in this report was not possible.

\section{Experimental}

\section{Chemistry}

${ }^{1} \mathrm{H}-\mathrm{NMR}$ and ${ }^{13} \mathrm{C}-\mathrm{NMR}$ spectra were recorded in $\mathrm{CDCl}_{3}$ on a JEOL ECX-300. Mass spectral data were collected on a Hewlett-Packard GCD Plus. For antimicrobial assays and spectral analysis, compounds were purified by preparative chromatography with a 
Gow-Mac Series 580 using a $2 \mathrm{~m}$ by $5 \mathrm{~mm}$ column that had a 3\% OV101 liquid phase. Sample purity for antimicrobial assays was confirmed by GC-MS analysis. The GC-MS analyses were performed on a $\mathrm{CH}_{2} \mathrm{Cl}_{2}$ solution of the purified sample in a splitless mode (0.5 min), using a Hewlett-Packard GCD Plus fitted with a 30-m $\times 0.25-\mathrm{mm}$ cross-linked phenyl methyl silicone capillary column (HP-5MS). The gas chromatograph was programmed so the oven temperature was kept at $40^{\circ} \mathrm{C}$ for $4 \mathrm{~min}$, then increased to a final temperature of $325^{\circ} \mathrm{C}$ at a rate of $30^{\circ} \mathrm{C} / \mathrm{min}$ and held at this temperature for $5 \mathrm{~min}$.

\section{Synthesis of 3,4-Epoxy-2-alkanones (2a-2g)}

To a stirred solution $\left(20^{\circ} \mathrm{C}\right)$ of 0.005 mole of the appropriate $(E)-3$-alken-2-one [3] in $20 \mathrm{~mL}$ of methanol and $1.5 \mathrm{~mL}$ of $30 \% \mathrm{H}_{2} \mathrm{O}_{2}$, was added $0.4 \mathrm{~mL}$ of $6 \mathrm{M} \mathrm{NaOH}$, dropwise over 1 minute. After stirring for $10 \mathrm{~min}$ at RT, the reaction was quenched with $25 \mathrm{~mL}$ of water and then extracted into $2 \times 25 \mathrm{~mL}$ of diethyl ether. The ether solution was washed with $2 \times$ $50 \mathrm{~mL}$ water, dried over sodium sulfate and concentrated in vacuo. The compounds were purified by preparative gas chromatography.

\section{3,4-Epoxy-2-undecanone (1-(3-heptyloxiran-2-yl)ethanone, 2a)}

Yield 64\%. Liquid, $300 \mathrm{MHz}{ }^{1} \mathrm{H}-\mathrm{NMR}\left(\mathrm{CDCl}_{3}\right) \delta=3.14(\mathrm{~d}, 1 \mathrm{H}, \mathrm{J}=4.8 \mathrm{~Hz}), 3.03(\mathrm{dt}, 1 \mathrm{H}$, $\mathrm{J}=12.9 \mathrm{~Hz}, \mathrm{~J}=4.8 \mathrm{~Hz}), 2.02(\mathrm{~s}, 3 \mathrm{H}), 1.58(\mathrm{~m}, 2 \mathrm{H}), 1.42(\mathrm{~m}, 2 \mathrm{H}), 1.23(\mathrm{~m}, 8 \mathrm{H})$ and $0.84(\mathrm{t}$, $3 \mathrm{H}) ; 75 \mathrm{MHz}{ }^{13} \mathrm{C}-\mathrm{NMR}\left(\mathrm{CDCl}_{3}\right) \delta=206.18,59.89,58.09,31.71,31.64,29.15,29.03$, 25.71, 24.31, 22.54, and 14.00; and El-MS m/z = 100(6), 85(98), 82(7), 81(15), 69(8), 67(9), 57(30), 55(23), 43(100) and 41(27).

\section{3,4-Epoxy-2-dodecanone (1-(3-octyloxiran-2-yl)ethanone, 2b)}

Yield 70\%. Liquid, $300 \mathrm{MHz}{ }^{1} \mathrm{H}-\mathrm{NMR}\left(\mathrm{CDCl}_{3}\right) \delta=3.14(\mathrm{~d}, 1 \mathrm{H}, \mathrm{J}=4.8 \mathrm{~Hz}), 3.03(\mathrm{dt}, 1 \mathrm{H}$, $\mathrm{J}=12.9 \mathrm{~Hz}, \mathrm{~J}=4.8 \mathrm{~Hz}), 2.02(\mathrm{~s}, 3 \mathrm{H}), 1.58(\mathrm{~m}, 2 \mathrm{H}), 1.42(\mathrm{~m}, 2 \mathrm{H}), 1.23(\mathrm{~m}, 10 \mathrm{H})$ and $0.84(\mathrm{t}$, $3 \mathrm{H}) ; 75 \mathrm{MHz}{ }^{13} \mathrm{C}-\mathrm{NMR}\left(\mathrm{CDCl}_{3}\right) \delta=206.12,59.89,58.07,31.76,31.72,29.35,29.21$, 29.09, 25.72, 24.29, 22.58, and 14.03; and El-MS $\mathrm{m} / \mathrm{z}=100(7), 85(100), 82(7), 81(15)$, 69(14), 67(9), 57(31), 55(20), 43(91) and 41(26).

\section{3,4-Epoxy-2-tridecanone (1-(3-nonyloxiran-2-yl)ethanone, 2c)}

Yield 80\%. Liquid, $300 \mathrm{MHz}{ }^{1} \mathrm{H}-\mathrm{NMR}\left(\mathrm{CDCl}_{3}\right) \delta=3.14(\mathrm{~d}, 1 \mathrm{H}, \mathrm{J}=4.8 \mathrm{~Hz}), 3.03(\mathrm{dt}, 1 \mathrm{H}$, $\mathrm{J}=12.9 \mathrm{~Hz}, \mathrm{~J}=4.8 \mathrm{~Hz}), 2.02(\mathrm{~s}, 3 \mathrm{H}), 1.58(\mathrm{~m}, 2 \mathrm{H}), 1.42(\mathrm{~m}, 2 \mathrm{H}), 1.23(\mathrm{~m}, 12 \mathrm{H})$ and $0.84(\mathrm{t}$, $3 \mathrm{H}) ; 75 \mathrm{MHz}{ }^{13} \mathrm{C}-\mathrm{NMR}\left(\mathrm{CDCl}_{3}\right) \delta=206.12,59.90,58.07,31.80,31.73,29.41,29.37$, 29.25, 29.20, 25.71, 24.30, 22.61, and 14.04; and El-MS m/z = 95(19), 85(100), 81(7), 81(12), 69(13), 67(10), 57(29), 55(20), 43(90) and 41(26).

\section{3,4-Epoxy-2-tetradecanone (1-(3-decyloxiran-2-yl)ethanone, 2d)}

Yield 79\%. Liquid, $300 \mathrm{MHz}{ }^{1} \mathrm{H}-\mathrm{NMR}\left(\mathrm{CDCl}_{3}\right) \delta=3.14(\mathrm{~d}, 1 \mathrm{H}, \mathrm{J}=4.8 \mathrm{~Hz}), 3.03(\mathrm{dt}, 1 \mathrm{H}$, $\mathrm{J}=12.9 \mathrm{~Hz}, \mathrm{~J}=4.8 \mathrm{~Hz}), 2.02(\mathrm{~s}, 3 \mathrm{H}), 1.58(\mathrm{~m}, 2 \mathrm{H}), 1.42(\mathrm{~m}, 2 \mathrm{H}), 1.23(\mathrm{~m}, 14 \mathrm{H})$ and $0.84(\mathrm{t}$, $3 \mathrm{H}) ; 75 \mathrm{MHz}{ }^{13} \mathrm{C}-\mathrm{NMR}\left(\mathrm{CDCl}_{3}\right) \delta=206.12,59.88,58.07,31.82,31.72,29.50,29.43$, 29.38, 29.24, 29.20, 25.70, 24.28, 22.62, and 14.03; and El-MS m/z = 95(14), 85(87), 83(10), 81(11), 69(11), 67(10), 57(28), 55(22), 43(100) and 41(31).

\section{3,4-Epoxy-2-pentadecanone (1-(3-undecyloxiran-2-yl)ethanone, 2e)}

Yield 80\%. Liquid, $300 \mathrm{MHz}{ }^{1} \mathrm{H}-\mathrm{NMR}\left(\mathrm{CDCl}_{3}\right) \delta=3.14(\mathrm{~d}, 1 \mathrm{H}, \mathrm{J}=4.8 \mathrm{~Hz}), 3.03(\mathrm{dt}, 1 \mathrm{H}$, 
$\mathrm{J}=12.9 \mathrm{~Hz}, \mathrm{~J}=4.8 \mathrm{~Hz}), 2.02(\mathrm{~s}, 3 \mathrm{H}), 1.58(\mathrm{~m}, 2 \mathrm{H}), 1.42(\mathrm{~m}, 2 \mathrm{H}), 1.23(\mathrm{~m}, 16 \mathrm{H})$ and $0.84(\mathrm{t}$, $3 \mathrm{H}) ; 75 \mathrm{MHz}{ }^{13} \mathrm{C}-\mathrm{NMR}\left(\mathrm{CDCl}_{3}\right) \delta=206.19,59.90,58.09,31.85,31.73,29.60,29.56$, 29.39, 29.30, 29.28, 29.21, 25.72, 24.30, 22.63, and 14.06; and El-MS m/z = 95(14), 85(87), 83(9), 81(13), 69(12), 67(11), 57(29), 55(23), 43(100) and 41(31).

\section{3,4-Epoxy-2-hexadecanone (1-(3-dodecyloxiran-2-yl)ethanone, 2f)}

Yield 74\%. Liquid, $300 \mathrm{MHz}{ }^{1} \mathrm{H}-\mathrm{NMR}\left(\mathrm{CDCl}_{3}\right) \delta=3.14(\mathrm{~d}, 1 \mathrm{H}, \mathrm{J}=4.8 \mathrm{~Hz}), 3.03(\mathrm{dt}, 1 \mathrm{H}$, $\mathrm{J}=12.9 \mathrm{~Hz}, \mathrm{~J}=4.8 \mathrm{~Hz}), 2.02(\mathrm{~s}, 3 \mathrm{H}), 1.58(\mathrm{~m}, 2 \mathrm{H}), 1.42(\mathrm{~m}, 2 \mathrm{H}), 1.23(\mathrm{~m}, 18 \mathrm{H})$ and $0.84(\mathrm{t}$, $3 \mathrm{H}) ; 75 \mathrm{MHz}{ }^{13} \mathrm{C}-\mathrm{NMR}\left(\mathrm{CDCl}_{3}\right) \delta=206.18,59.91,58.08,31.85,31.75,29.60,29.57$, $29.45,29.40,29.29,29.21,25.74,24.32,24.21,22.66$, and 14.06 and El-MS m/z = 95(13), 85(77), 83(10), 81(12), 69(12), 67(10), 57(28), 55(23), 43(100) and 41(31).

\section{3,4-Epoxy-2-heptadecanone (1-(3-tridecyloxiran-2-yl)ethanone, 2g)}

Yield 74\%. Solid, $300 \mathrm{MHz}{ }^{1} \mathrm{H}-\mathrm{NMR}\left(\mathrm{CDCl}_{3}\right) \delta=3.14(\mathrm{~d}, 1 \mathrm{H}, \mathrm{J}=4.8 \mathrm{~Hz}), 3.03(\mathrm{dt}, 1 \mathrm{H}$, $\mathrm{J}=12.9 \mathrm{~Hz}, \mathrm{~J}=4.8 \mathrm{~Hz}), 2.02(\mathrm{~s}, 3 \mathrm{H}), 1.58(\mathrm{~m}, 2 \mathrm{H}), 1.42(\mathrm{~m}, 2 \mathrm{H}), 1.23(\mathrm{~m}, 2 \mathrm{H})$ and $0.84(\mathrm{t}$, $3 \mathrm{H}) ; 75 \mathrm{MHz}{ }^{13} \mathrm{C}-\mathrm{NMR}\left(\mathrm{CDCl}_{3}\right) \delta=206.19,59.92,58.08,31.89,31.75,29.57,29.57$, $29.57,29.45,29.40,29.29,29.21,25.74,24.32,24.22,22.66$, and 14.09; and EI-MS $\mathrm{m} / \mathrm{z}=$ 95(12), 85(66), 83(10), 81(11), 69(13), 67(10), 57(29), 55(22), 43(100) and 41(32).

\section{Antimicrobial Assay}

The 3,4-epoxy-2-alkanones were screened against some mammalian skin pathogens: the bacteria Staphylococcus aureus, ATCC 12598, Propionibacterium acnes ATCC 11827; and the fungi Candida albicans ATCC 24433, Pityrosporum ovale ATCC 14521 and Trichophyton mentagrophytes ATCC 18748. The minimum inhibitory concentration (MIC in $\mu \mathrm{g} / \mathrm{mL}$ ) of these 3,4-epoxy-2-alkanones was done using a two-fold serial broth dilution. Two replicates were done with each microorganism and the MIC was determined as the lowest concentration for each compound at which no growth was observed. The highest concentration used in these tests was $800 \mu \mathrm{g} / \mathrm{mL}$.

Each test compound ( $80 \mathrm{mg}$ ) was dissolved in $1.0 \mathrm{~mL}$ of dimethylformamide (DMF) and 30 $\mu \mathrm{L}$ of this stock solution was dissolved in $3 \mathrm{~mL}$ of the applicable medium. Two-fold serial dilution of the resulting $800 \mu \mathrm{g} / \mathrm{mL}$ solution, gave solutions of $400,200,100,50,25,12.5$, 6.25 , and $3.12 \mu \mathrm{g} / \mathrm{mL}$. In addition, for each microorganism, a control of $30 \mu \mathrm{L}$ DMF in $3 \mathrm{~mL}$ of medium was tested. Finally, to each of the diluted test solutions was added a $30 \mu \mathrm{L}$ sample of microorganism culture. The cultures of $S$. aureus, $P$ acnes and $C$. albicans were examined for turbidity (OD at $660 \mathrm{~nm}$ ). $P$. ovale was examined visually for growth at two days and $T$. mentagrophytes at five days.

T. mentagrophytes lyophile was reconstituted in sterile water and grown on media containing $1 \%$ peptone and $4 \%$ glucose. A seven-day-old plate of well sporulating pure culture was washed and resuspended in $1 \mathrm{~L}$ of media. A $30 \mu \mathrm{L}$ sample of this culture was dispensed into each $3 \mathrm{~mL}$ sample of the diluted test solutions (1\% peptone and $4 \%$ glucose). The $13 \times 100 \mathrm{~mm}$ glass culture tubes with Morton cap closures were incubated at $30^{\circ} \mathrm{C}$.

$P$. acnes lyophile was reconstituted in sterile media and grown in screw cap tubes at $37^{\circ} \mathrm{C}$ in media containing $0.8 \%$ nutrient broth, $0.5 \%$ yeast extract, $0.1 \%$ glucose to which $1 \%$ Oxyrase (Oxyrase, Inc.) was added after autoclaving. At two days, a $30 \mu \mathrm{L}$ sample of this 
culture was mixed with each diluted test solution $[0.8 \%$ nutrient broth (BBL), $0.5 \%$ yeast Extract (Difco) and 0.1\% glucose (NYG broth)]. The $13 \times 100 \mathrm{~mm}$ glass culture tubes with Morton cap closures were incubated at $37^{\circ} \mathrm{C}$.

P. ovale was shake-cultured in $1 \%$ bactopeptone (Difco), $0.5 \%$ yeast extract, $1 \%$ glucose and $0.1 \%$ corn oil for two days at $30^{\circ} \mathrm{C}$. C. albicans was shake-cultured in a $2.5 \%$ malt extract broth $(\mathrm{BBL})$ for two days at $30^{\circ} \mathrm{C}$. S. aureus was incubated for two days at $37^{\circ} \mathrm{C}$ in a culture media containing $0.8 \%$ nutrient broth (BBL), $0.5 \%$ yeast Extract (Difco) and $0.1 \%$ glucose (NYG broth).

\section{Conclusions}

Preorbital glands are common among ungulates, which usually mark twigs and grass with their contents as a chemical cue to other members of the species [9, 10]. Because of scent marking in cases like this, almost all animal skin glands are usually referred to as "scent glands." While the semiochemical function of these animal skin glands has been the focus of research in this area, a further function of these glands may be to produce antimicrobial compounds against dermal pathogens. Antimicrobial compounds found in these glands may be biosynthesized by the animal itself, or by microbes that live in these glands. Prospecting for antimicrobial compounds from animal skin glands followed by synthesis of appropriate analogues is an area of drug discovery that has been largely unexplored and has the potential of producing new antimicrobial agents against pathogenic dermal organisms.

\section{Acknowledgement}

The Darrel Nielson Institute and the Humboldt State University Foundation are thanked for support of this research.

\section{Author's Statement}

\section{Competing Interests}

The author declares no conflict of interest.

\section{References}

[1] Wood WF, Shaffer TB, Kubo A.

(E)-3-Tridecen-2-one, an antibiotic from the interdigital glands of black-tailed deer Odocoileus hemionus columbianus.

Experientia. 1995; 51: 368-369.

doi:10.1007/BF01928897

[2] Wood WF, Shaffer TB, Kubo A.

Volatile ketones from interdigital glands of black-tailed deer, Odocoileus hemionus columbianus.

J Chem Ecol. 1995; 21: 1401-1408.

doi:10.1007/BF02035141

[3] Wood WF, Kubo A, Shaffer TB.

Antimicrobial activity of long-chain (E)-3-alken-2-ones.

Bioorg Med Chem Lett. 2010; 20: 1819-1820.

doi:10.1016/j.bmcl.2010.02.016 
[4] Wood WF, Szewczak. JM.

Volatile Antimicrobial Compounds in the Pelage of the Mexican Free-tailed Bat, Tadarida brasiliensis mexicana.

Biochem Syst Ecol. 2007; 35: 566-568.

doi:10.1016/j.bse.2007.04.002

[5] Wood WF, Weldon PJ.

The scent of the reticulated giraffe (Giraffa camelopardalis reticulata).

Biochem Syst Ecol. 2002; 30: 913-917.

doi:10.1016/S0305-1978(02)00037-6

[6] Wood WF.

Antibacterial compounds in the interdigital glands of pronghorn, Antilocapra americana.

Biochem Syst Ecol. 2001; 29: 417-419.

doi:10.1016/S0305-1978(00)00060-0

[7] Burger BV, Pretorius PJ, Spies HS, Bigalke' RC, Grierson GR.

I Mammalian pheromones. VIII: chemical characterization of preorbital gland secretion of grey duiker, Sylvicapra grimmia (Artiodactyla: Bovidae).

J Chem Ecol. 1990; 16: 397-416.

doi:10.1007/BF01021773

[8] Wasson RL, House HO.

The Rearrangement of $\alpha, \beta$-Epoxy Ketones. V. Rearrangements Resulting in Ring Contraction.

J Am Chem Soc. 1957; 79: 1488-1492.

doi:10.1021/ja01563a058

[9] Albone ES.

Mammalian Semiochemistry.

New York: John Wiley \& Sons, 1984.

[10] Burger BV.

Mammalian Semiochemicals.

In: The Chemistry of Pheromones and other Semiochemicals II.

Schulz S; Ed.

Berlin: Springer-Verlag, 2005: 231-278.

doi:10.1007/b98318 